\title{
Climatic change and its effects on Agri-Horti Sector (A study of the district Baramulla of J\&K)
}

\author{
Aadil Altaf Lone \\ Barkatullah University \\ India \\ Tariq Ahmad Guroo \\ Research Scholar Department of Political Science \\ Barkatullah University
}

\begin{abstract}
The present paper will focus on effects of climatic change on agriculture and horticulture sector of Kashmir valley and will also study how it affects the socio-economic profile of framers. Climatic change is affecting all regions of the globe which not only effects the production but it also disturbs the normal life in Kashmir valley. Due to the climatic change the occurrence of floods, draughts, heat and cold waves are common across the world and have adverse impact on the livelihood of billions of people who depend on land for most of their needs. It is more important in Kashmir as the state's economy is entirely depending on agriculture and horticulture sector. As we know the weather of Kashmir valley is entirely different from other states of India. The effects of global warming which results late snowfall and abrupt decrease in temperature in the spring season which results huge damage of crops and fruit cultivation in Kashmir valley. The need of the hour is that such problems should be undertaken seriously in the states of Jammu and Kashmir as it is the backbone of economy, if it remains same the whole nation will suffer. In this study we will analyze the whole scenario of the climatic change of Kashmir with respect to agriculture and horticulture and will summarize the issues and problems which are faced by the farmers of the Kashmir. This paper will also highlight some issues at the end which should be implemented at the ground level to overcome from such issues and problems because the state is wholly and solely dependent on the agri-horti sector. The objectives of the paper are how climatic change affects the agriculture and horticulture sector of Kashmir valley and the second objective of the study is to know how it affects the socio-economic condition of farmers in Kashmir valley.
\end{abstract}

KEYWORDS: Agriculture, Kashmir, Affects Horticulture, Climatic, Change.

\section{Introduction:}

Climate change is emerging as perhaps the greatest environmental challenge of the twenty first century. Climate change and agriculture are interrelated processes, both of which take place on a global scale. Climate change or global warming is the most serious environmental threats of the 21 st centuries. Global warming is projected to have significant impacts on conditions affecting agriculture, including temperature, carbon dioxide, glacial run-off, precipitation and the interaction of these elements.. The climate is changing all over the world that adversely affects different social groups differently. The agriculture is one of the sectors which are adversely affected by climate change and has adverse impacts on agriculture and agriculture relevant stakeholders. Among all the stakeholders, the farmer community is the most affected and risk group due to their full dependency on agriculture. The phenomenon of climate change and global warming is predicted to create a serious threat not only to humans but its adverse impact encompasses the

http://dx.doi.org/10.19085/journal.sijbpg040901 
ecosystems whole. Global climate change is a change in the long-term weather patterns that characterize the regions of the world. In the long run, the climatic change could affect agriculture in several ways such as quantity and quality of crops in terms of productivity, growth rates, photosynthesis and transpiration rates, moisture availability etc. Climate change is likely to directly impact food production across the globe. Increase in the mean seasonal temperature can reduce the duration of many crops and hence reduce the yield. Drivers of climate change through alterations in atmospheric composition can also influence food production directly by its impacts on plant physiology. The consequences of agriculture's contribution to climate change, and of climate change's negative impacts on agriculture, are severe which is projected to have a great impact on food production and may threaten the food security and hence, require special agricultural measures to fight with. Cultivation practices changes occur because Weather records show that snowfall has decreased as the winters are now warmer than two-three decades back in the Himalayas. Over the years, extreme reduction in snowfall has caused reduction in soil moisture which has tempted changes in cultivation practices. The rising temperature, erratic rainfall, unexpected frost and hailstorm, and emergence of new pests and diseases are symptoms of climate change. Normally in Shopian the snowfall as per previous records occurred in months of December up to march. However from past few years pattern of snowfall has changed due to Global warming. As a result early booming of apple buds occurs in rainy seasons due to which flowers did not receive optimum temperature for growth and pollination. Thus reduction of apple production is observed however recent use of synthetic pollinators in form of photohormones has increased the net production of apples.

\section{Climate of Kashmir valley:}

Climate of Kashmir valley is entirely different from other states of India. The state has different climates which are entirely different from other states of India and completely different from the globe. Climate which we can define as weather conditions of a particular region over a long period of time. The valley of Kashmir is having six weather seasons and each season is having a difference of two months which almost starts from $15^{\text {th }}$ day of month. The climate seasons are like *sont, *grishm, *warat, *harud *wandh and *shishr. The first season starts from March 15 to May 15, May 15 to July 15, July 15 to Sep.15, Sep15 to Nov.15, Nov15 to Jan.15, and Jan15 to March15(Lawrence, 2011)[1].These are the Kashmiri names and there is no specific names for them in other language. The rest of the world and other states of India have four climatic seasons in a year like spring summer autumn and winter. The climate of Kashmir valley is widely different in all six climatic seasons, in sont season the people of Kashmir usually doing the farming practices were farming is mostly dependent on rains and particularly in sont season the weather remains wet. In sont season (spring) people of Kashmir valley start their agricultural practices in their fields were rains play an important role but if the season remains dry or too wet then it has adverse impact on agricultural productivity and on socio economic life of farmers. The season which starts after sont is known as grishm (summer) this season starts from the month of 15th May to 15th July. In this season the agricultural farmers doing the same job as in sont season but in this season the crops are in such stage 
which needs moderate temperature or suitable temperature which helps the crops to grow and helps in boosting the productivity and help the farmers in their socio economic development. The season which is almost dry and remains hot, in such stage it is necessary that there should be some rains in the middle of the stage if there is late any way has direct effect on agricultural and fruit crops which is one of the effects of climatic change on agriculture and horticulture sector. The next climatic season starts from the month of $15^{\text {th }}$ July to $15^{\text {th }}$ September which is known as the pre harvesting season in Kashmir valley. The farmers usually in this season harvest there ripped agricultural and fruit cultivation and store or sell them in different markets. In this particular season the wet climate can damage the crop cultivation of agricultural farmers and can damage the socio economic life of people which not only has adverse effects on farmers but too on other sectors of society. This season is also known as the achievement season for farmers because in this season the farmers get the reward what actually they sow and harvest. The actual harvesting season in Kashmir valley starts from the month of 15 th September to 15 th November. In this season the farmers harvest their fruit as well as agricultural crops. Climatic change in such stage or in harvesting seasonhave an adverse impact on farmers as well as on other sectors of society because the majority of population in the state dependent on agriculture horticulture directly or indirectly for their livelihood. The season in Kashmiri language is known as (harud) the autumn season of Kashmir valley. People in such season remain busy in their fields and if there are some rains or climate remains cloudy brings tensions to the people and disturb the whole environment and people which get their livelihood from agricultural or horticultural fields also did not get there daily wages properly. Another climatic season of Kashmir valley starts from the month of November $15^{\text {th }}$ which continues to $15^{\text {th }}$ of January which is very hard season in Kashmir valley because the whole season remains wet and chilly. The temperature in this season reaches to minus where it is hard to move or do any practice. The whole valley remains under the white snow, the roads remain block, cut off from the electricity and business activities remain closed. In this season people mostly remains inside their homes and schools and colleges remain closed. In this season people wear different warm clothes and different kinds of electronic devices are available to get rid of from the coldness. In this season the people in Kashmir valley mostly remains jobless which has a direct adverse impact on their socio economic life because the valley is known for agricultural and horticultural practices due to snow, wet climate, chillness and single crop cultivation the socio economic development of valley lacks here. The last climatic season of Kashmir valley is shishr which starts from the $15^{\text {th }} \mathrm{Jan}$ to $15^{\text {th }}$ March. The climate in this season remains too cold, temperature also remains minus and all the streams, lakes, the things will remain outside the homes or sheds shall melt into ice which is the signs of this season. In this season the whole valley looks beautiful but people of Kashmir suffers too. The climate of Kashmir valley is entirely different from others states of the India as well as the globe where people should remain cautious of everything like heavy snowfall can damage the property of fruit growers like break down of trees, down fall of temperature damages the production and heavy snow fall can damage the infrastructural property of common men. These are the big challenges behind every man to tackle and these are the serious effects of climatic change which can disturb the socio economic well-being of the people. In brief we can say that we 
must protect environment from odd things so it may not have any adverse effects on our socio economic development. If there is any abrupt change in climate made some strange changes in the life of people which are whole and solely dependent on agri-horti for their livelihood.

\section{Objectives of the study:}

To study how climatic change affects the agriculture and horticulture sector of Kashmir valley.

To study how climatic change affects the socio-economic condition of farmers in Kashmir valley.

\section{Hypotheses:}

The climatic change affects the agriculture and horticulture sector of Kashmir valley.

The climatic change affects the socio-economic condition of farmers in Kashmir valley.

\section{Map of town sopore:}

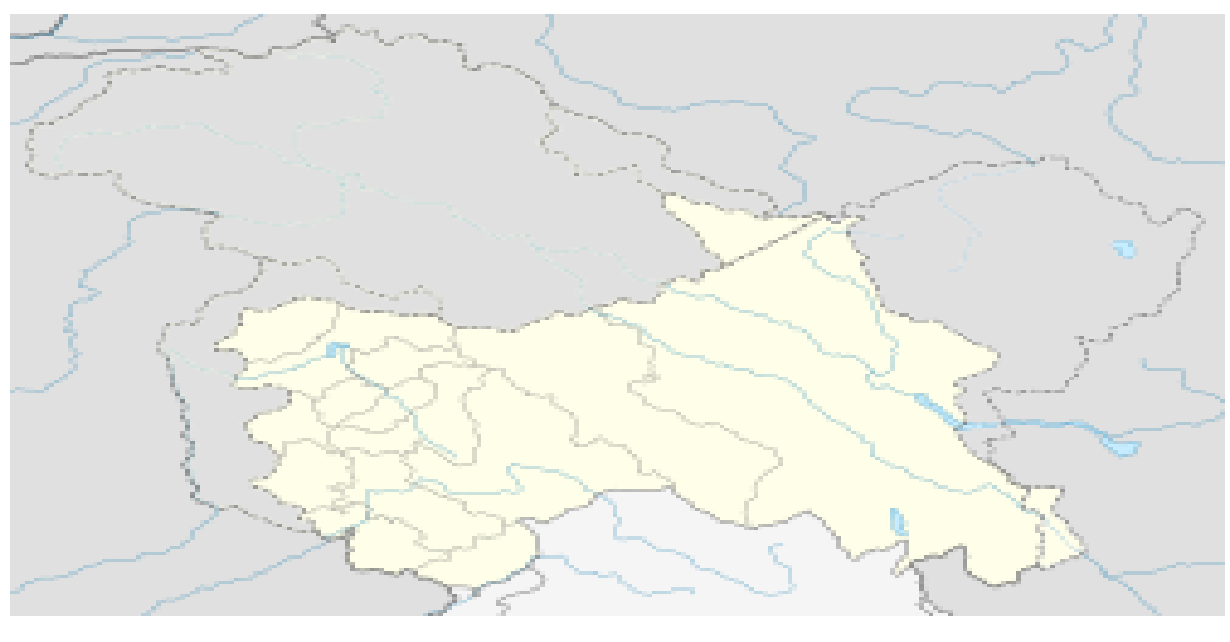

Source: $\underline{\text { ttps://en.wikipedia.org/wiki/File:India_Jammu_and_Kashmir_location_map_UN_view.svg }}$

\section{Area of study:}

Baramulla is as old as the valley of Kashmir. In ancient times called Varamulla, it is situated at a distance of $55 \mathrm{kms}$ from the summer capital of Jammu \& Kashmir State, in the north, east of Srinagar. Baramulla which is known as the hub of fruits and sopore town is one of the largest subdivisions of the state with 7 tehsils and it is also the oldest existing subdivision of the state.Sopore town was founded in $880 \mathrm{AD}$ during the rule of King Avantivarman, and lies at a distance of $48 \mathrm{~km}$ from the district of Srinagar on the banks of the river Jhelum. It is the biggest trade Centre of the North Kashmir region and is known among tourists as the 'apple town of Asia'. The apples of Sopore are regarded as the best in the entire continent. Sopore, also known as the London of Kashmir, is renowned among people for its rapidly growing sectors of horticulture and agriculture. The town of Sopore is famous for the Jamia Masjid, Khan-kah Shah-i-Hamdan and several small shrines. Shiekh Hamza Makhdoomi Tujar, Arza Sahib Takya Khan Zainagair, Daid Mouj Mundji, 
Baba Shukur Din Watlab Sopore and Hathi-Shah Sahib are some of the other popular shrines located in Sopore. The site is also scattered with a few Hindu pilgrimage sites such as Kali Mandir, Shiv Mandir, Rishi peer Mandir located at Batpora and Bhairon Mandir. .https://www.nativeplanet.com/baramulla/attractions/sopore/[2]

\section{Methodology:}

As the approach followed in most social science research the present study is based on the both primary as well as secondary source of the data collection. (Climatic change and its effects on agri-horti sector (A study of district Baramulla of $\mathbf{J} \mathbf{K} \mathbf{K}$ ) forthis study ten villages were selected from district Baramulla of state Jammu and Kashmir. The villages were selected randomly for the study and Interview method was used for data collection consisting of structured questions keeping in view the objectives of the study. Social background information was collected through interview schedule which includes information about age, education, family type, social participation and source of information of the respondents. Other section of the tool deals with the questions to obtain information regarding the effects of climatic change on agrihorticulture sector of Kashmir valley and reason behind the effects of climatic change. Data collection is being done by conducting personal interview at door to door and in agricultural and horticultural fields.

\section{Universe \& Selection of Sample:}

The selected district is one of the largest districts with respect to population or land is concerned. The total population of the district as per census 2011 is 1008039 persons .It consists of 534733 males and 473306 females. The rural sector of the district is inhabited by 432399 males and 393140 females. The district constitutes 8 tehsils and 12 community Development blocks. (Census, 2011)[3]. Baramulla is as old as the valley of Kashmir. In ancient times called Varamulla, it is situated at a distance of $55 \mathrm{kms}$ from the summer capital of Jammu \& Kashmir State, in the north, east of Srinagar. It is surrounded by mountains from three sides, which give this town an extra ordinary beautiful look. Baramulla being the district headquarters comprises of 8 tehsils. This district has been divided in 12 Community Development Blocks. The total numbers of villages are 518. (Census, 2011)[4] The district which is also known as the hub of fruits and in this paper we made some efforts how climatic changes effects agricultural and fruit cultivations, for such attempt we select our respondents from commercialized hub (fruit Mundie sopore) constituted of numerous fruit sheds with almost a bulk of merchandisers, out of which we have selected only three sheds for present study. From each shed only15 respondents were selected randomly for the collection of research data in relation to the demographic composition of the Baramulla. In this way, 45 respondents were selected in total from the concerned universe. Before interviewing the respondents a thorough study was conducted in the area to collect the necessary information regarding the agriculture and fruits crops in the district. After that with the help of random sampling, 15 respondents from each fruit shed were selected for the collection of research data. There are many research designs to carry out the research or fieldwork on a particular type of research problem such as experimental research design, descriptive research design and exploratory 
research design. As far as our research is concerned, exploratory research design has been used in the present work. The data available to us revealed that our problem can be studied further for more research work as it has been suggested by exploratory research design (Guroo, 2016) [5].

\section{Fruit Mundie Sopore:}

Sopore mundi is the second largest fruit mundi in Asia which is situated in the north Kashmir in sopore town. Sopore fruit mundi is located near village Nowpora which is $1 \mathrm{~km}$ away from sopore town, whole people of this village is working in this mundi. Sopore mundi covers the area about 372 canals which is established in 1987-1988. The sopore mundi have near about 30 sale platforms, each platform consists of 10 foods. The total fud sin sopore mundi is near about 300 . The number of growers affiliated with sopore mundi is above 900. Sopore mundi is considered the biggest fruit mundi in Jammu and Kashmir. Sopore mundi has the distinction of exporting more than 50\% of the total production of apples produced in Kashmir valley. Sopore mundi supplies apples almost in every state in our country, it supplies apples near about 129 stations in India. The market gives employment opportunities near about 1.5 lakh people (directly or indirectly). According to traders near about 265 crores fruit business is being carried out in sopore mundi every year. However the lack of infrastructure is hobbling the growth of business as it prevents the foreign buyers to come to the mundi.The fruit growers and dealers alleged that the state govt. has failed to pay any attention towards up grading its infrastructure. The mundi have a potential to become one of the best fruit market in the region, if efforts are made to improve its infrastructure so, that diversification of the apples takes place in food processing sector.
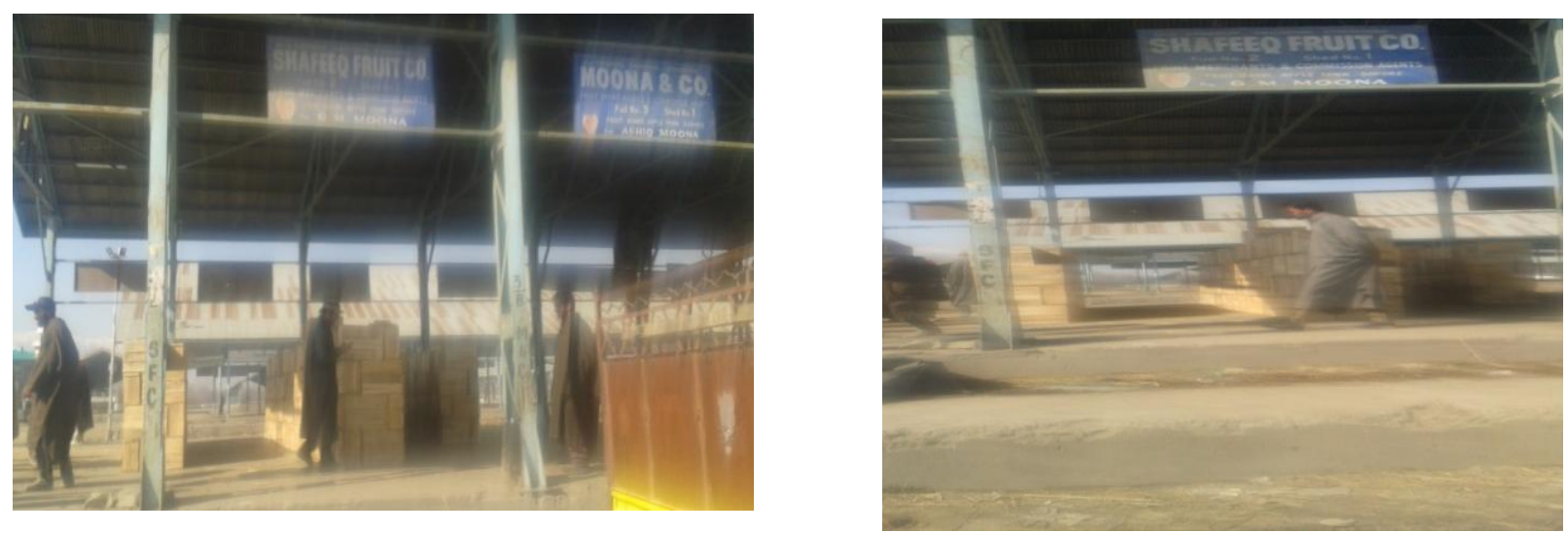

SOPORE FRUIT MANDI

Fruit mundi sopore

\section{Construction / Development of sopore mundi:}

The fruit mundi sopore is one of the big market in state $\mathrm{j} \& \mathrm{k}$ where annual business turnover is at an average of Rupees 265 crores. The development of sopore mundi approved in the year 1987- 
1988. It consists off near about 30 plate-forms which covers about 300 fuds each fud bearing a specific name and Mark and covers an area of 372 canals. An expenditure of Rs 812.865 lakhs were spend till 2007 - 2008 from premium and Rupees 642.86 lakhs from plan micromanagement. An amount of rupees 111.27 lakhs has been spend during 2009 and Rupees 150.00 lathes has been spend for development for this mundi during annual plan 2012-2013.

Table 1

\section{Profile of respondents:}

\begin{tabular}{|c|c|c|c|c|c|c|c|c|c|}
\hline \multirow[t]{2}{*}{ Selected Fuds } & \multicolumn{2}{|c|}{ Gender Status } & \multicolumn{2}{|c|}{ Marital Status } & \multicolumn{2}{|c|}{$\begin{array}{l}\text { Educational } \\
\text { Status }\end{array}$} & \multicolumn{3}{|c|}{ Age status } \\
\hline & M & $\mathrm{F}$ & $\mathrm{Ma}$ & $\mathrm{Um}$ & Lit. & Ilit. & $18-28$ & $29-39$ & 40-above \\
\hline Shed no.01 & 15 & - & 12 & 03 & 08 & 07 & 04 & 08 & 03 \\
\hline Shed no.02 & 15 & - & 11 & 04 & 11 & 04 & 03 & 09 & 03 \\
\hline Shed no.03 & 15 & - & 08 & 07 & 10 & 05 & 04 & 08 & 03 \\
\hline Total & 45 & - & 31 & 14 & 29 & 16 & 11 & 25 & 09 \\
\hline
\end{tabular}

From district Baramulla of Kashmir valley, we have selected fruit mundi sopore as our study area and randomly we have selected three sheds for data collection and from each shed we have taken 15 respondents, in which all respondents are male. On the basis of marital status among 45 respondents, 31 are married and 14 are unmarried and by the educational wise distribution 29 are literates and16 are illiterates. The above table graph shows that out of 45 respondents, 11 belong to $18-28$ age group, 25 belong to $29-39$ age group and 09 belong to 40 above age group.

\section{Analysis:}

\section{Do you know about climate change?}

\begin{tabular}{|l|r|r|}
\hline Know about climate change & Responses & Percentage \\
\hline Yes & 30 & 66.67 \\
\hline To some extent & 12 & 26.67 \\
\hline No & 3 & 6.67 \\
\hline Total & 45 & 100 \\
\hline
\end{tabular}

The data shows that among 45 respondents 30 respondents are well known about climatic change. The respondents that know little bit about climatic change and they are 12 respondents and the respondents that did not know about climatic change and the number of respondents are 3 only. 
What are the factors responsible for climate change?

\begin{tabular}{|l|r|r|}
\hline Factors responsible & Responses & Percentage \\
\hline Overpopulation & 9 & 20 \\
\hline Deforestation & 10 & 22.22 \\
\hline Greenhouse gases & 8 & 17.78 \\
\hline All the above & 18 & 40 \\
\hline Total & 45 & 100 \\
\hline
\end{tabular}

The analysis of above table reveals that out of 45 respondents $20 \%$ respondents agreed that over population is one of the factors responsible for climatic change. Deforestation not only demolishes the greenery but is the most responsible factor which effect climate and the numbers of respondents which are with this statement are $22.22 \%$. Greenhouse gases also have bad impact on climate and the numbers of respondents are $17.78 \%$ and the respondents which believe that all the mentioned statements are responsible for climatic changes the figure also shows that $40 \%$ respondents are with this statement.

\section{Does climatic change have worse impact on agriculture/horticulture sector of Kashmir valley?}

\begin{tabular}{|l|r|r|}
\hline Worse impact of clamitic change & Responses & Percentage \\
\hline High & 20 & 44.44 \\
\hline To some extent & 15 & 33.33 \\
\hline Low & 10 & 22.22 \\
\hline Total & 45 & 100 \\
\hline
\end{tabular}

The above mentioned table shows that $44.44 \%$ respondents answered that agriculture and horticulture sector of Kashmiri valley especially district Baramulla suffer most by climatic change, $33.33 \%$ said that climatic change has to some extent effect on agri- horticulture sector of Kashmir valley and the respondents that agreed that climatic change has low impact on agriculture and horticulture sector of Kashmir valley and the numbers of respondents are $22.22 \%$.

\section{Whatare the main effects of climatic change on agriculture and horticulture sector?}

\begin{tabular}{|l|r|r|}
\hline Main effects & Responses & Percentage \\
\hline Low production & 22 & 48.89 \\
\hline Damage crops & 15 & 33.33 \\
\hline Other & 8 & 17.78 \\
\hline Total & 45 & 100 \\
\hline
\end{tabular}

It is quite clear from the above table that $48.89 \%$ respondents agreed that low production is the main effect of climatic change. The climatic change also damages the crops when there are heavy rains, hailstorms, winds and the numbers of respondents are $33.33 \%$ and the respondents that agreed that there are other effects of climatic change and the figure shows that they are $17.778 \%$. 
Was climatic change responsible for increase in production sometimes?

\begin{tabular}{|l|r|r|}
\hline Responsible for production increase & Responses & Percentage \\
\hline Yes & 34 & 75.56 \\
\hline N o & 11 & 24.44 \\
\hline Total & 45 & 100 \\
\hline
\end{tabular}

The tabled data shows that about $75.56 \%$ respondents believe that climatic change is responsible for increase in production sometimes and the number of respondents which are against this statement are $24.44 \%$.

Do you agree that due to climatic change the socio-economic life of farmers getting disturbed?

\begin{tabular}{|l|r|r|}
\hline Socio economic life disturb & Responses & Percentage \\
\hline Strongly agree & 21 & 46.67 \\
\hline Agree & 10 & 22.22 \\
\hline Undecided & 2 & 4.44 \\
\hline Strongly disagree & 7 & 15.56 \\
\hline Disagree & 5 & 11.11 \\
\hline Total & 45 & 100 \\
\hline
\end{tabular}

The analysis of above table reveals that $46.67 \%$ strongly agree that due to climatic change the socio economic life of common people especially the farmers getting disturbed. About $22.22 \%$ respondents agree, $4.44 \%$ respondents are with the statement of undecided. The numbers of respondents which strongly disagree that the socio economic life of farmers did not getting worried by climatic change and the numbers of respondents are $15.56 \%$ and the numbers of respondents which are with the statement of disagree and total numbers of respondents are $11.11 \%$.

Is government organizing any programmers and policies regarding climatic changes?

\begin{tabular}{|l|r|r|}
\hline Govt. policies and programmes & Responses & Percentage \\
\hline Yes & 13 & 28.89 \\
\hline Some times & 5 & 11.11 \\
\hline No & 27 & 60 \\
\hline Total & 45 & 100 \\
\hline
\end{tabular}

The role of government plays a decent role in country's development especially in the rural areas of Kashmir valley were people are directly or indirectly depend on agriculture and horticulture sector. The govt. policies and programmers regarding climatic change should be effective but in the present time this thing is somewhat new for people because govt. is not interested in these things and they suffer a lot. The numbers of respondents that agreed with the statement that govt policies and programmers are not help full for common people especially climatic change is concerned they are not providing any information related to climatic change and the numbers of respondents are $60 \%$. The respondents which agreed with the http://dx.doi.org/10.19085/journal.sijbpg040901 
statement that sometimes govt policies and programmers are helpful and they are $11.11 \%$ respondents and the respondents which are with the yes statement and agreed that govt. is organizing programmers regarding climatic change and they are $28.89 \%$.

Is government providing any compensation due to adverse effects of climatic change on agriculture and horticulture?

\begin{tabular}{|l|r|r|}
\hline Compensation & Responses & Percentage \\
\hline Yes & 10 & 22.22 \\
\hline Some times & 5 & 11.11 \\
\hline No & 30 & 66.67 \\
\hline Total & 45 & 100 \\
\hline
\end{tabular}

Due to any natural disaster whether it in form of floods, hail storms, wind storms, earth quick etc. role of govt is necessary and essential thing to overcome from such disaster because govt. is having such capacity and capability to help their generation of people. Among these disasters climatic change is one of the effective challenges for the farmers and the respondents which agreed that govt is providing them any relief at the bad time the figure shows that they are $22.22 \%$. Some of our respondents agreed that sometimes govt. is providing compensation to the impacted farmers and the respondents are $11.11 \%$ and in the last statement (NO) respondents that agreed that the govt. is not providing anything to the farmers at the time of any disaster and the numbers of respondents are $66.66 \%$ which indicates that govt. support is essential for betterment of country and for the betterment of development.

\section{If yes, then what are the modes of compensation?}

\begin{tabular}{|l|r|r|}
\hline Mode of compensation & Responses & Percentage \\
\hline Cash payment & 10 & 22.22 \\
\hline Distribution of fertilizers and seeds & 20 & 44.44 \\
\hline Distribution of plants & 8 & 17.78 \\
\hline Other & 7 & 15.56 \\
\hline Total & 45 & 100 \\
\hline
\end{tabular}

In the above mentioned table sometimes govt. is providing compensation to the impacted farmers. The govt. distributes it to the people in the form of cash payment and the numbers of respondents are $22.22 \%$. Sometimes govt. distributes in the solid form like fertilizers and seeds and the numbers of respondents are $44.44 \%$. The respondents answered that sometimes govt. distributes it in the form of plants and they also guide us and provide us fertilizers and insecticides to the plants which they distribute to the famers and the numbers of respondents are $17.78 \%$ and the respondents which agreed with the statement (other) are $15.56 \%$ in this statement respondents either blame that govt is not providing good enough and some blame that they are not disturbing it in the impacted framers. 


\section{Conclusion:}

Climatic change is affecting all regions of the globe which not only effects the production but it also disturbs the normal life in Kashmir valley. Due to the climatic change the occurrence of floods, draughts, heat and cold waves are common across the world and have adverse impact on the livelihood of billions of people who depend on land for most of their needs. It is more important in Kashmir as the state's economy is entirely depending on agriculture and horticulture sector. Kashmir Valley being primarily an agriculture economy faces the threat of climate change to a major extent. The growers have observed uneven distribution of winter, high temperature, etc. The area under food crops and fruits has shifted to off season crop cultivation.. There is a remarkable increase in area under offseason vegetable cultivation in Kashmir valley. Farmers are aware of the increasing uncertainties of weather. Govt. intervention is the prime requirement to overcome from such hardships and need of the hour is that agriculturists and government should play their active role in country's development. Agriculture is highly sensitive to climate changes and weather extremes, such as droughts, floods and severe storms. It is estimated that greater loss is expected in Rabi as compared to Kharif crops and especially in productivity and quality apple.

\section{References:}

[1] Census of India, 2011

[2] https://www.nativeplanet.com/baramulla/attractions/sopore/ [accessed on 14, dec.2017]

[3] Dr. Musadiq Amin Shah ,1986 " marketing problems of apple industry in Kashmir valley ."

[4] Dr. Zeenat Dar ,1981, " Role of agriculture in the development of j\& k economy."

[5] Dr. Ghulam Mohammad , 1994 , " a comparative analysis of apple production of j\&k and Himachal Pradesh ." 